Determinants of Delay in Audit Reporting in Companies Conducting IPOs (Initial Public Offerings)

\title{
Determinan Keterlambatan Pelaporan Audit Pada Perusahaan Yang Melakukan IPO (Initial Public Offerings)
}

\author{
Yofhi Septian Panglipurningrum ${ }^{1}$, T.Husain ${ }^{2}$ \\ STIE Adi Unggul Bhirawa (AUB) Surakarta ${ }^{1}{ }^{1}$ STMIK Widuri, Jakarta ${ }^{2}$ \\ Email: Yofhi.septian@stie-aub.ac.id, thusain050686@gmail.com
}

\begin{abstract}
Delay in audit reporting is an important issue for investors. Companies that carry out Initial Public Offerings (IPO) in 2019 have their own challenges in the firm's performance, whether to extend, remain, or even shorten the Audit Delay. This study aims to re-examine the determinants of Profitability, Audit Opinion, and Size of Public Accounting Firm (PAF) in their effect on Audit Delay. This type of causality research underlies this research with a quantitative approach. The final sample of the study was set at 53 companies. Methods of data analysis using multivariate analysis with multiple linear regression. The study results resulted in an average Audit Delay of 104.49 days, even though there is a 2-month delay due to the COVID-19 pandemic. Audit Delay is not influenced by the determinants of Profitability, Audit Opinion, and KAP Size.
\end{abstract}

Keyword: Audit Delay, IPO, Audit Opinion

\begin{abstract}
Abstrak
Keterlambatan pelaporan audit menjadi persoalan penting bagi investor. Perusahaan-perusahaan yang melakukan Initial Public Offerings (IPO) di tahun 2019 memiliki tantangan tersendiri dalam kinerja perusahaannya apakah akan memperpanjang, tetap atau bahkan justru justru dapat memperpendek Audit Delay. Penelitian ini bertujuan untuk menguji kembali determinan Profitabilitas, Opini Audit dan Ukuran Kantor Akuntan Publik (KAP) dalam pengaruhnya terhadap Audit Delay. Jenis penelitian kausalitas mendasari penelitian ini dengan pendekatan kuantitatif. Sampel akhir penelitian ditetapkan sebanyak 53 perusahaan. Metode analisis data menggunakan analisis multivariat dengan regresi linier berganda. Hasil penelitian menghasilkan rata-rata Audit Delay selama 104,49 hari walaupun adanya penundaan 2 bulan akibat pandemi COVID-19. Audit Delay tidak dipengaruhi oleh determinan Profitabilitas, Opini Audit dan Ukuran KAP.

Kata Kunci: Hedging Instrumen Derivatif, Likuiditas, Leverage, Profitabilitas, Firm Size, Growth Opportunity.
\end{abstract}

\section{PENDAHULUAN}

Keterlambatan pelaporan audit menjadi persoalan penting bagi investor. Investor tentunya akan sangat mempertimbangkan waktu rilis laporan ini untuk masalah investasi sehingga adanya penundaan akan mengurangi nilai informasi itu sendiri untuk pengambilan keputusan mereka (SEC, 2002; Lai, 2019). Pentingnya ketepatan waktu menjadi faktor utama untuk memberikan gambaran kualitatif secara menyeluruh kepada seluruh stakeholders' agar mereka dapat meramal atau memprediksi dan bahkan dapat memberikan nilai umpan balik atas informasi yang tertuang pada laporan keuangan (Ocak \& Özden, 2018).

Rilis laporan keuangan yang diaudit secara cepat, tepat waktu serta memiliki informasi yang handal tentunya tidak terlepas dari serangkaian proses dan lingkungan organisasi yang mendukung dan terlibat seperti faktor kota, faktor politik serta faktor audit itu sendiri yang merupakan unsur terpenting untuk menggerakkan berbagai sumberdaya perusahaan dan mekanisme pengendalian baik staf ahli internal maupun eksternal yaitu dalam rangka mengurangi penundaan audit (Cohen \& Leventis, 2013). Sistem komputerisasi yang melibatkan pemanfaatan electronic data processing systems (EDPS), management or accounting information systems (M/AIS) dan banyak hal lainnya yang mencakup dalam enterprise resource planning (ERP) juga menjadi bagian yang tidak terpisahkan dari pengambilan keputusan manajemen (Husain T. , 2017). Faktor audit dan teknologi di atas tentunya dimiliki oleh auditor atau Kantor Akuntan Publik (KAP) untuk merumuskan perencanaan, prosedur, dan program audit yang memadai dalam mencapai ketepatan waktu pelaporan keuangan setiap termin bagi perusahaan-perusahaan publik serta dapat mengurangi penundaan audit (audit delay), dimana hal tersebut tentunya akan disorot oleh stakeholders'.

Penelitian mengenai audit delay tentunya tidak menjadi persoalan di negara-negara maju dan 
sebagian negara berkembang. Hasil perbedaan antara peneliti yang satu dengan lainnya (inkonsistensi) disebabkan belum mendalamnya pembahasan mengenai audit delay pada studi empiris di Indonesia terkait dengan faktor-faktor tertentu (Rusdiyanto, Agustia, Soetedjo, Narsa, \& Fitrisia, 2020). Beberapa studi menghasilkan temuan penelitian pada jurnal internasional mengenai keterlambatan dan penundaan laporan audit antara lain: (1) Faktor yang berhubungan dengan audit report lag melalui studi empiris menggunakan 171 sampel perusahaan non-keuangan selama tahun 2011-2013 di Mesir, hasil penelitian menyatakan hubungan negatif antara honorarium audit yang dibayarkan lebih tinggi untuk mengurangi risiko audit yang berdampak pada audit report lag (ARL) dan menghasilkan 77 hari rata-rata sejak akhir tanggal neraca hingga tanggal laporan audit ditandatangani (Ezat, 2015); (2) Faktor karakteristik spesifik pada auditor yang menandatangani laporan audit atas audit report lag menggunakan data 968 perusahaan dari Borsa Istanbul selama 2008-2013, dengan hasil kriteria KAP Big-4 serta opini audit mendorong klien audit untuk menyajikan laporan keuangan tepat waktu. Selain itu, penundaan audit banyak disebabkan oleh kriteria spesifik auditor berdasarkan jenis kelamin, tingkat pendidikan pada perusahaan yang diaudit oleh perusahaan Big-4 dan selain Big-4 (Ocak \& Özden, 2018); (3) Faktor yang mempengaruhi audit delay melalui studi empiris menggunakan 34 sampel perusahaan bank umum konvensional periode 2014-2016 di Indonesia, hasil penelitian menyatakan reputasi KAP tidak memoderasi faktor ukuran perusahaan dan profitabilitas terhadap audit delay (Wijayanti, Machmuddah, \& Utomo, 2019); (4) Determinan audit delay melalui studi empiris menggunakan 142 sampel perusahaan foreign direct investment (FDI) di Vietnam, hasil penelitian menyatakan pengaruh negatif laporan laba bersih yang positif, opini audit dan ukuran perusahaan terhadap audit delay dan menghasilkan rata-rata audit delay selama 62,62 hari (Laia, Tranb, Hoang, \& Nguyen, 2020); dan (5) Faktor kualitas audit dengan proksi honorarium audit atas audit delay menggunakan data 42 data perusahaan manufaktur sub sektor Kabel dari Indonesia Stock Exchange (IDX) selama 2013-2019, hasil penelitian menyatakan kualitas audit memiliki pengaruh negatif yang signifikan terhadap audit delay dan menghasilkan rata-rata audit delay selama 83,62 hari (Husain \& Rini, 2020).

Hasil penelitian di atas dapat disimpulkan dan menjadi bukti bahwa audit delay dipengaruhi oleh beberapa faktor penting seperti Profitabilitas, Opini Audit, dan Ukuran Kantor Akuntan Publik (KAP). Faktor ini cukup banyak digunakan oleh penelitian terdahulu. Momentum di tahun 2020, setelah banyak negara yang merilis penundaan atas pelaporan audit tahunan ke publik pasar bursa akibat dampak global pandemi COVID-19 dengan rata-rata selama 2 hingga 4 bulan. Perusahaan-perusahaan yang melakukan Initial Public Offerings (IPO) dalam satu tahun sebelum kondisi ini akan menghadapi tantangan tersendiri dalam kinerja perusahaan melalui rilis laporan keuangan yang diaudit pada tahun 2020 karena disorot oleh banyak stakeholders', apakah akan memperpanjang, tetap atau bahkan justru dapat memperpendek audit delay. Oleh karena itu, perlu dilakukan penelitian ini untuk menguji kembali pengaruh faktor-faktor di atas dalam pengaruhnya terhadap audit delay pada perusahaanperusahaan yang IPO di tahun 2019.

\section{TINJAUAN PUSTAKA}

Teori kepatuhan yang diadopsi dari T. Tayler (1990), yang menfokuskan pada pentingnya mekanisme sosialisasi seorang individu dalam rangka perilaku atas suatu kepatuhan, teori ini digunakan oleh ilmuwan bidang sosial khususnya bidang sosiologi (Palilingan, 2017). Berdasarkan lampiran Keputusan Ketua Bapepam Nomor KEP-346/BL/2011 tertanggal 5 Juli 2011 tentang kewajiban Penyampaian Laporan Berkala Emiten atau Perusahaan Publik, dalam kaitannya dengan compliance theory dan audit delay, aturan ini mengisyaratkan bahwa adanya kewajiban perilaku individu maupun organisasi (perusahaan publik) yang terlibat di pasar modal untuk menyampaikan laporan keuangan tahunan perusahaan secara tepat waktu (BAPEPAM, 2011). Oleh karena itu, kepatuhan perusahaan publik menjadi suatu keharusan dalam memenuhi prinsip tranparansi pengungkapan informasi dalam pelaporan keuangan secara tepat waktu. Perusahaan yang terdaftar di pasar bursa di Indonesia diwajibkan terlebih dahulu diaudit oleh Kantor Akuntan Publik (KAP) dalam menyampaikan laporan keuangan tahunan. OJK dalam Pasal 7 Ayat (1) mengatur waktu penyampaian laporan keuangan tahunan selambat-lambatnya pada akhir bulan keempat setelah tahun buku berakhir (OJK, 2016). Audit delay dapat didefinisikan sebagai acuan waktu dari akhir tahun keuangan perusahaan hingga ditandatanganinya laporan audit (Cohen \& Leventis, 2013), atau dengan kata lain selisih antara tanggal tutup buku perusahaan dengan tanggal dirilisnya opini audit.

Profitabilitas merupakan salah satu jenis rasio keuangan yang menggambarkan kelangsungan 
perusahaan dengan ukuran kemampuan perusahaan dalam menghasilkan benefit atau keuntungan yang dilaporkan kepada para stakeholders'. Untuk dapat mengetahui apakah laba tersebut memang layak untuk sebagai pertimbangan tolok ukur maka salah satu cara yang dapat digunakan adalah dengan melakukan analisis imbas hasil atau tingkat pengembalian aset. Pengembalian total aset dikaitkan dengan operasi efektivitas umum manajemen dalam menghasilkan laba dengan aset yang tersedia (Gitman \& Zutter, 2015, hal. 81). Lebih lanjut, profitabilitas juga merupakan indikator berita baik atau berita buruk atas kinerja perusahaan dengan pengukuran ROA (Palilingan, 2017).

Opini Audit adalah output atau produk yang memuat suatu pernyataan kategori pendapat yang diberikan oleh praktisi atau individu (seorang auditor) kepada auditee-nya atas laporan keuangan yang telah dilakukan suatu audit untuk menentukan apakah laporan keuangan tersebut memiliki kriteria unqualified opinion atau kriteria lainnya. Menurut Standar Profesional Akuntan Publik (PSA 29 SA, Seksi 508) terdapat 5 (lima) jenis pendapat akuntan, yaitu: (1) Pendapat wajar tanpa pengecualian (Unqualified Opinion); (2) Pendapat wajar tanpa pengecualian dengan bahasa penjelasan yang ditambahkan dalam laporan audit bentuk baku (Unqualified opinion report with explanatory language); (3) Pendapat wajar dengan Pengecualian (Qualified Opinion); (4) Pernyataan tidak memberikan pendapat (Disclaimer Opinion); dan (5) Pendapat tidak wajar (Adverse Opinion) (Agoes, 2012, hal. 53). Auditor yang dinyatakan sebagi pihak yang independen dalam evaluasi laporan keuangan suatu perusahaan akan memberikan opini atas laporan keuangan yang diauditnya sebagaimana diatur dalam Standar Profesi Akuntan Publik (SPAP). Bagian dari laporan audit yang merupakan informasi utama dari laporan audit adalah opini audit yang didasarkan pada keyakinan profesional seorang auditor eksternal. Keandalan pelaporan laporan keuangan tidak hanya dapat dicapai dengan meng-hire auditor dari kategori Big Four. Faktanya, mekanisme faktor penegakan independensi yang buruk terkadang mengganggu auditor ketika dihadapkan pada kepemilikan keluarga dan investor walaupun yang melibatkan KAP tersebut (Abid, Shaique, \& Anwar ul Haq, 2018; Husain, Pasupati, \& Quintania, 2020)

Kantor Akuntan Publik (KAP) adalah bentuk organisasi akuntan publik yang memperoleh izin sesuai dengan peraturan perundang-undangan yang berusaha di bidang pemberian jasa profesional dalam publik akuntan publik (Agoes, 2012, hal. 43). Pengkategorian KAP dapat dikelompokkan sebagai berikut: (1) Kantor Akuntan Publik Internasional "Big Four"; (2) Kantor Akuntan Publik Nasional; (3) Kantor Akuntan Publik Regional dan Lokal Besar; dan (4) Kantor Akuntan Publik Lokal Kecil (Arens, Elder, \& Beasley, 2014, hal. 26). Kantor akuntan publik yang populer dikenal dengan istilah" Big Four" yang terdiri dari PricewaterhouseCoopers (PWC), Ernst \& Young (EY), Deloitte Touche, dan KPMG. Empat kantor akuntan publik ini memiliki kantor-kantor yang tersebar di Amerika Serikat dan seluruh dunia yang melakukan audit atas dominasi sebagian besar perusahaan besar dan perusahaan yang lebih kecil baik di Amerika Serikat maupun di seluruh dunia.

Pentingnya audit delay sebagai fungsi determinan dalam memprediksi profitabilitas, opini audit dan ukuran KAP pada penelitian ini diperlukan suatu kerangka berpikir. Menurut Uma Sekaran, kerangka berfikir merupakan model konseptual tentang bagaimana teori berhubungan dengan berbagai faktor yang telah didefinisikan sebagai masalah yang penting untuk diteliti (Sugiyono, 2017, hal. 91), sementara model itu sendiri dapat dinyatakan atas konstruk melalui parameter spesifik yang diukur baik dalam bentuk, struktur, isi, jumlah dan makna dengan batasan tertentu (Husain T. , 2019). Basis latar belakang, penelitian terdahulu dan kajian pustaka yang diuraikan, maka penelitian ini mengajukan model penelitian sebagai berikut:

Gambar 1. Model Penelitian

\begin{tabular}{|c|c|}
\hline $\begin{array}{c}\text { Profitabilitas, Opini Audit, } \\
\text { Ukuran KAP } \\
(\mathrm{X} 1 ; \mathrm{X} 2 ; \mathrm{X3})\end{array}$ & $\begin{array}{c}\text { AUDIT DELAY } \\
(\mathrm{Y})\end{array}$ \\
\cline { 2 - 2 }
\end{tabular}

Sumber: Dikembangkan dalam Penelitian ini

Model penelitian di atas dikembangkan dalam perumusan hipotesis dalam memberikan jawaban atas determinan faktor yang berdampak pada audit delay. Profitabilitas merupakan salah satu pengukuran yang populer dan disepakati di kalangan akademis dan praktisi untuk menggambarkan kinerja perusahaan. Perusahaan yang memiliki profitabilitas yang tinggi tentunya memotivasi pihak manajemen untuk menginformasikan kepada publik kinerja dengan mengeluarkan laporan tahunan 
yang diaudit secara lebih awal, atau dengan kata lain memperpendek audit delay. Beberapa hasil riset seperti Friso Palilingan (2017) dan Yashinta Putri Wijayanti, dkk. (2019) serta Thi Thu Thuy Lai et al. (2020) yang membuktikan cukup bukti faktor profitabilitas dapat memperpendek audit delay. Temuan riset Afina Survita Prameswari dan Rahmawati Hanny Yustrianthe (2015) juga memberikan bukti signifikansi atas faktor profitabilitas dengan arah yang positif serta temuan riset Murat Ocak dan Evrim Altuk Özden (2018) dalam konteks audit report lag sementara temuan riset Yohanes Baptista Tupen Ebang, dkk. (2019) yang tidak memberikan bukti faktor profitabilitas mempengaruhi audit delay. Temuan riset di atas memiliki beberapa gap, sehingga melatarbelakangi untuk kembali merumuskan hipotesis alternatif berikut ini:

$\mathrm{H}_{1}$ : Profitabilitas berpengaruh terhadap Audit Delay

Opini Audit tertuang dalam laporan auditor independen yang dirilis oleh organisasi Kantor Akuntan Publik sebagai wujud bahwa informasi keuangan sudah siap untuk didistribusikan kepada stakeholders'. Opini audit dengan kriteria unmodified juga memotivasi pihak manajemen untuk menginformasikan kepada publik hasil evaluasi kinerja perusahaan secara lebih awal, dibandingkan dengan kriteria modified. Beberapa hasil riset seperti Friso Palilingan (2017) yang membuktikan cukup bukti faktor opini audit berdampak pada audit delay. Temuan riset Amr Nazieh Mahmoud Ezat (2015) yang menjelaskan bahwa kualitas laporan secara positif berhubungan atas keterlambatan pelaporan. Temuan riset Murat Ocak dan Evrim Altuk Özden (2018) bahwa hasil opini audit mendorong perusahaan audit untuk menyajikan laporan keuangan secara tepat waktu sementara temuan riset Yohanes Baptista Tupen Ebang, dkk. (2019) yang tidak memberikan bukti faktor opini audit mempengaruhi audit delay. Temuan riset di atas memiliki beberapa gap, sehingga melatarbelakangi untuk kembali merumuskan hipotesis alternatif berikut ini:

$\mathrm{H}_{2}$ : Opini Audit berpengaruh terhadap Audit Delay

Ukuran KAP menggambarkan skala atau besar kecilnya suatu kantor akuntan. Selain itu, ukuran KAP dalam perspektif luas juga menjadi ukuran kualitas audit berdasarkan kategori Big Four. Kualitas audit berdasarkan insentif atau honorarium tidak selalu melibatkan KAP Big Four tetapi tetap menggunakan kriteria afiliasi internasional dibandingkan dengan KAP lokal dalam konteks di Pemerintah kota Yunani (Cohen \& Leventis, 2013). Dua kelompok ini (Big Four) dan bukan Big Four menjadi pengukuran kualifikasi dari jenis audit (Ezat, 2015). Beberapa hasil riset seperti Amr Nazieh Mahmoud Ezat (2015), Friso Palilingan (2017), dan Rusdiyanto, dkk. (2020) yang membuktikan cukup bukti faktor ukuran KAP berdampak pada audit delay dan audit report lag. Temuan riset Afina Survita Prameswari dan Rahmawati Hanny Yustrianthe (2015) juga memberikan bukti signifikansi atas faktor profitabilitas dengan arah yang positif sementara temuan riset Thi Thu Thuy Lai et al. (2020) serta T. Husain dan I Gusti Ayu Intan Saputra Rini (2020) yang membuktikan cukup bukti faktor kualitas audit dapat memperpendek audit delay. Temuan riset Yohanes Baptista Tupen Ebang, dkk. (2019) dan juga Yashinta Putri Wijayanti, dkk. (2019) yang tidak memberikan bukti faktor ukuran KAP mempengaruhi audit delay. Temuan riset di atas memiliki beberapa gap, sehingga melatarbelakangi untuk kembali merumuskan hipotesis alternatif berikut ini:

$\mathrm{H}_{3}$ : Ukuran KAP berpengaruh terhadap Audit Delay

\section{METODE}

Jenis penelitian kausalitas mendasari dalam memberikan penjelasan serta mengukur hubungan casual effect antar variabel sebagai dasar dalam menganalisis beberapa variabel tersebut (Supranto \& Limakrisna, 2019, hal. 13). Penelitian ini menggunakan pendekatan kuantitatif yaitu berlandaskan pada filsafat positivisme, digunakan untuk meneliti populasi atau sampel tertentu menggunakan analisis data bersifat kuantitatif atau statistik, dengan tujuan untuk menguji hipotesis yang telah ditetapkan (Sugiyono, 2017, hal. 7). Penelitian ini menggunakan subjek penelitian berupa perusahaan yang melakukan Initial Public Offerings (IPO) di Bursa Efek Indonesia (BEI) selama tahun 2019. Operasionalisasi variabel penelitian yaitu:

Tabel 1. Operasionalisasi Variabel

\begin{tabular}{cccc}
\hline Variabel & Proksi & Pengukuran & Referensi \\
\hline Profitabilitas & ROA & $\frac{\text { Net Income }}{\text { Total Assets }}$ 100\% & (Gitman \& Zutter, 2015, hal. 81) \\
\hline Opini Audit & OPINION & "1" jika opini audit & (Ahmed \& Hossain, 2010; Ezat, \\
\hline
\end{tabular}




\begin{tabular}{|c|c|c|c|}
\hline Variabel & Proksi & Pengukuran & Referensi \\
\hline & & $\begin{array}{c}\text { Qualified, dan "0" jika selain } \\
\text { selain Qualified }\end{array}$ & 2015; Ocak \& Özden, 2018) \\
\hline Ukuran KAP & BIG & $\begin{array}{l}\text { "1" jika perusahaan diaudit } \\
\text { oleh kategori KAP Big Four, } \\
\text { dan "0" jika selain Big Four }\end{array}$ & $\begin{array}{l}\text { (DeAngelo, 1981; Svanström, } \\
\text { 2013; Ezat, 2015; Ocak \& Özden, } \\
\text { 2018; Husain \& Syniuta, 2020) }\end{array}$ \\
\hline Audit Delay & AUDELAY & $\begin{array}{c}\text { Selisih antara tanggal tutup } \\
\text { buku perusahaan dan opini } \\
\text { audit }\end{array}$ & $\begin{array}{l}\text { (Ashton, Willingham, \& Elliott, } \\
\text { 1987; Cohen \& Leventis, 2013) }\end{array}$ \\
\hline
\end{tabular}

Sumber: Develop by this research

Teknik penetapan sampel menggunakan metode total sampling sebanyak 53 (lima puluh tiga) perusahaan dari 55 (lima puluh lima) perusahaan yang dijadikan populasi, 2 (dua) perusahaan diantaranya tidak memiliki data lengkap yang dibutuhkan dalam penelitian ini. Sumber data penelitian ini meliputi data sekunder yaitu data yang diperoleh dari website resmi perusahaan dan Bursa Efek Indonesia (www.idx.co.id) berupa laporan tahunan dan keuangan pada perusahaan yang melakukan IPO di tahun 2019.

Metode analisis data menggunakan analisis multivariat, yaitu analisis yang berhubungan dengan cara yang dipergunakan dalam pengolahan data dengan menggunakan statistik dalam upaya mencapai tujuan dari suatu penelitian yang menggunakan pendekatan inferensial (Santosa A. D., 2019, hal. 3). Analisis ini mempergunakan metode analisis regresi linier berganda dengan regresi yang dikalkulasikan adalah:

$$
\begin{array}{ll}
\text { AUDELAY }=a+\beta 1 R O A \\
\text { dimana: AUDELAY } & =\text { Audit Delay } \\
\alpha & =\text { Konstanta } \\
\beta(1 ; 2 ; 3) & =\text { Koefisien regresi } \\
\text { ROA } & =\text { Profitabilitas } \\
\text { OPINION } & =\text { Opini Audit } \\
\text { BIG } & =\text { Ukuran KAP } \\
\mathrm{e} & =\text { faktor penggangu }
\end{array}
$$

\section{HASIL PENELITIAN DAN PEMBAHASAN}

Hasil statistik deskriptif atas determinan audit delay berdasarkan faktor profitabilitas, opini audit dan ukuran KAP yaitu:

\begin{tabular}{lllll}
\multicolumn{5}{c}{ Tabel 2. Deskriptif } \\
\hline Min. & Max & Mean & Std. Dev \\
\hline ROA & $-0,1010$ & 0,1600 & 0,024736 & 0,0494244 \\
OPINION & 0 & 1 & 0,08 & 0,267 \\
BIG & 0 & 1 & 0,11 & 0,320 \\
AUDELAY & 49 & 181 & 104,49 & 32,596 \\
\hline
\end{tabular}

Sumber: Data Diolah (2020)

Hasil deskriptif variabel penelitian atas pengukuran ROA yang menjelaskan profitabilitas perusahaan menghasilkan nilai rata-rata sebesar 0,024736, artinya imbas hasil pengembalian aset pada sampel penelitian memiliki nilai yang cukup rendah yaitu 2,47 persen. Pengukuran OPINION yang menjelaskan kategori jenis opini yaitu Qualified menghasilkan nilai rata-rata sebesar 0,08 atau hanya 8\% dari keseluruhan sampel penelitian sementara pengukuran BIG yang menjelaskan ukuran kantor akuntan publik berdasarkan kategori Big Four menghasilkan nilai rata-rata sebesar 0,11 artinya hanya 11 persen dari keseluruhan sampel penelitian yang diaudit oleh KAP Big Four dan sisanya diaudit oleh KAP selain Big Four. Pengukuran AUDELAY yang menjelaskan jumlah hari dalam penundaan audit pada sampel penelitian memiliki nilai rata-rata selama 104,49 hari, artinya masih memenuhi ketentuan OJK dalam batas waktu pelaporan yang selambat-lambatnya 4 bulan setelah tahun buku berakhir.

Uji asumsi klasik diawali dengan uji normalitas data dengan menampilkan grafik p-plots berikut ini: 


\section{Gambar 2. Hasil P-Plots}

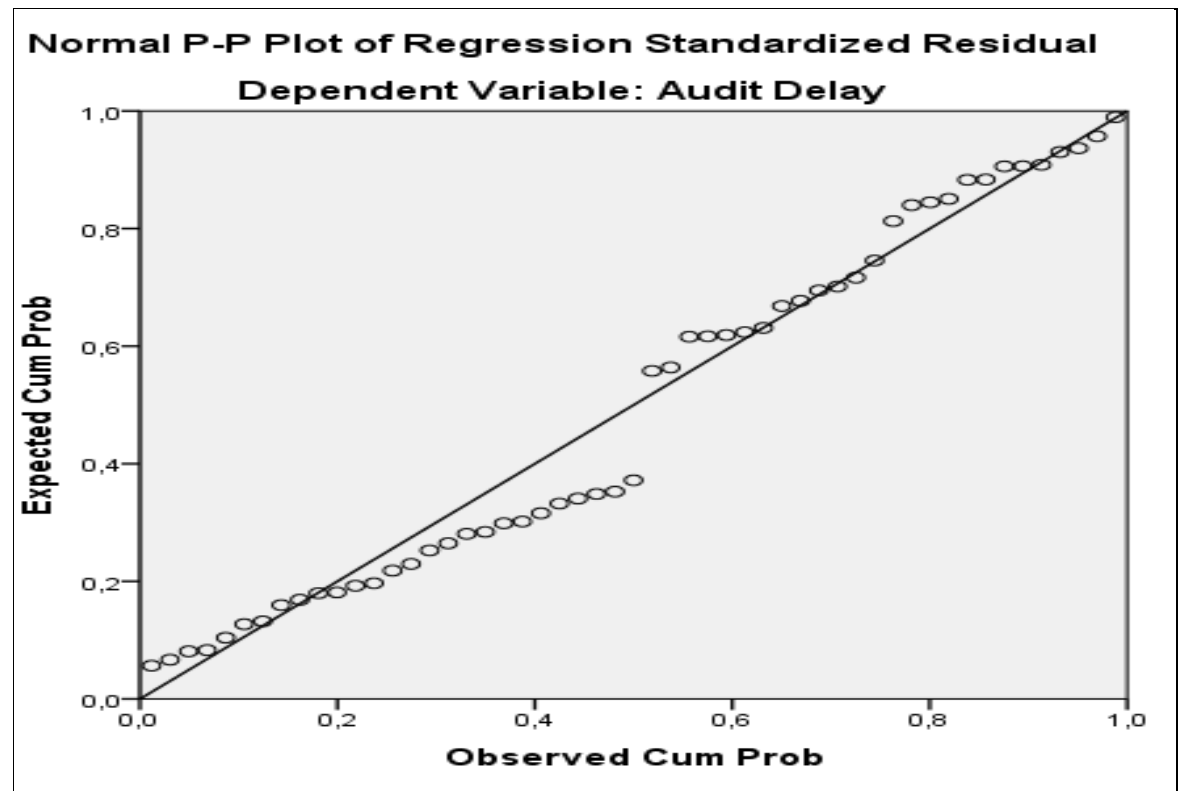

Sumber: Output Pengolahan Data (2020)

Sebaran data pada grafik p-plots menyebar di titik-titik pada garis diagonal dan mengikuti arah garis diagonal sehingga telah memenuhi uji normalitas data. Selanjutnya dilakukan uji heteroskedastisitas dengan menampilkan diagram scatter berikut ini:

Gambar 3. Hasil Scatter Diagrams

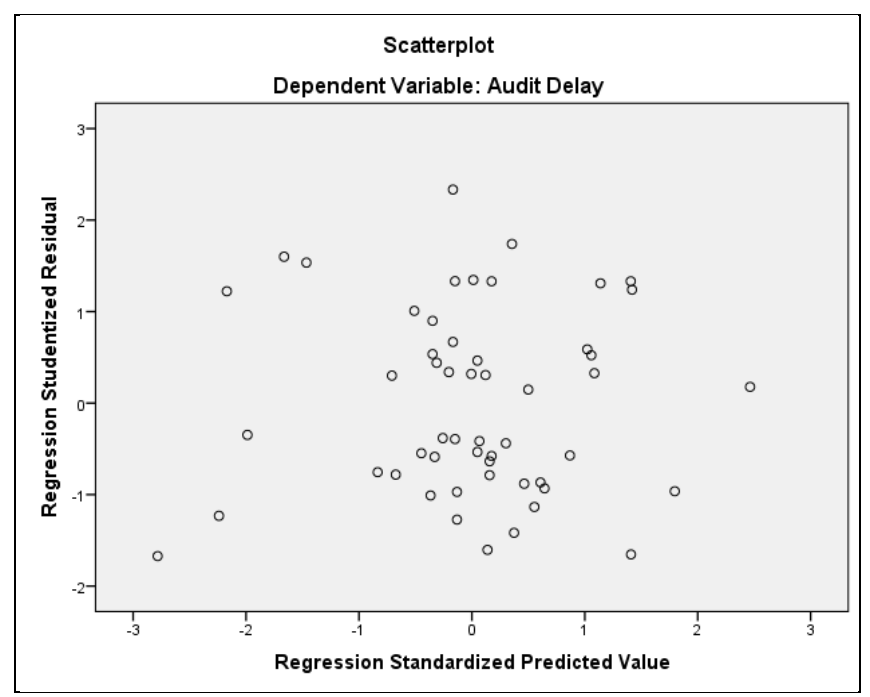

Sumber: Output Pengolahan Data (2020)

Sebaran grafik scatterplot tidak membentuk pola tertentu secara eksplisit, titik-titik menyebar di atas dan di bawah angka 0 pada sumbu Y, maka tidak terjadi gejala heteroskedastisitas. Selanjutnya dilakukan uji multikolinearitas dengan melihat skor tolerance dan variance inflation factors (VIF) dan yaitu:

Tabel 3. Hasil Uji Multikolinearitas

\begin{tabular}{llc}
\hline & Tolerance & VIF \\
\hline ROA & 0,972 & 1,028 \\
OPINION & 0,965 & 1,036 \\
BIG & 0,980 & 1,021 \\
\hline
\end{tabular}


Hasil uji multikolinearitas pada masing-masing variabel independen menghasilkan skor tolerance yang lebih dari (>) 0,1 sementara VIF masing-masing kurang dari $(<)$ skor 10, artinya dapat dinyatakan tidak terdapat gejala multikolinearitas. Oleh karena ketiga uji asumsi klasik telah memenuhi kriteria, maka dapat dilanjutkan ke tahapan uji hipotesis.

Tabel 4. Hasil Uji-t

\begin{tabular}{llccc}
\hline Model & $\begin{array}{l}\text { Koefien } \\
\text { Regresi }\end{array}$ & Skor t & $\begin{array}{c}\text { Probabilitas } \\
\text { Signifikansi }\end{array}$ & Keputusan \\
\hline Constant & 103,101 & 19,088 & 0,000 & - \\
ROA & 59,606 & 0,627 & 0,627 & Tolak $\mathrm{H}_{1}$ \\
OPINION & $-5,908$ & $-0,334$ & 0,740 & Tolak $\mathrm{H}_{2}$ \\
BIG & 3,188 & 0,218 & 0,828 & Tolak $\mathrm{H}_{3}$ \\
\hline
\end{tabular}

Sumber: Data Diolah (2020)

Hasil uji-t pada masing-masing variabel independen menghasilkan probabilitas signifikansi yang lebih dari (>) 0,05 sehingga menolak keseluruhan hipotesis alternatif $\left(\mathrm{H}_{1}, \mathrm{H}_{2}, \mathrm{H}_{3}\right)$ artinya masingmasing determinan yaitu Profitabilitas, Opini Audit dan Ukuran KAP tidak berpengaruh terhadap Audit Delay.

Determinan Profitabilitas dengan pengukuran Return on Assets (ROA), Opini Audit, dan Ukuran KAP dengan pengklasifikasian Big Four memiliki koefisien regresi masing-masing sebesar 59,606, minus 5,908 dan 3,188 dengan probabilitas signifikansi yang lebih besar dari 0,05 (Tabel 4) sehingga tidak menerima keseluruhan hipotesis alternatif, artinya tidak terbukti bahwa Profitabilitas, Opini Audit dan Ukuran KAP berpengaruh terhadap Audit Delay. Determinan penelitian ini tidak menentukan Audit Delay, perusahaan lebih cenderung memperhatikan kepatuhannya atau mendukung compliance theory terhadap ketentuan OJK yang memberikan batas waktu pelaporan pada perusahaan publik walaupun diperpanjang selama 2 (dua) bulan akibat pandemi COVID-19 menjadi Juni 2020 untuk pelaporan tahunan bagi bank dan emiten untuk laporan keuangan yang diaudit (OJK, 2020). Di samping itu, ketiga pengukuran di atas lebih mengarah pada tools atau alat monitoring stakeholders' dalam rangka mekanisme kepatuhan, dan pengawasan.

Determinan Profitabilitas pada temuan riset ini bertolak belakang dengan hasil penelitian terdahulu yang membuktikan atas pengaruh profitabilitas atas panjang atau pendeknya audit delay (Prameswari \& Yustrianthe, 2015; Palilingan, 2017; Ocak \& Özden, 2018; Wijayanti, Machmuddah, \& Utomo, 2019; Laia, Tranb, Hoang, \& Nguyen, 2020) sementara sejalan dengan hasil penelitian terdahulu yang tidak memberikan bukti faktor profitabilitas dalam mempengaruhi audit delay (Ebang, Fallah, \& Pangayow, 2019). Determinan Opini Audit pada temuan riset ini bertolak belakang dengan hasil penelitian terdahulu yang membuktikan atas pengaruh profitabilitas panjang atau pendeknya audit delay (Prameswari \& Yustrianthe, 2015; Palilingan, 2017; Ocak \& Özden, 2018; Wijayanti, Machmuddah, \& Utomo, 2019; Laia, Tranb, Hoang, \& Nguyen, 2020) sementara sejalan dengan hasil penelitian terdahulu yang tidak memberikan bukti faktor profitabilitas dalam mempengaruhi audit delay (Ebang, Fallah, \& Pangayow, 2019).

Opini Audit pada temuan riset ini bertolak belakang dengan hasil penelitian terdahulu yang membuktikan atas pengaruh opini audit atas panjang atau pendeknya audit delay (Ezat, 2015; Palilingan, 2017; Ocak \& Özden, 2018) sementara sejalan dengan hasil penelitian terdahulu yang tidak memberikan bukti faktor opini audit dalam mempengaruhi audit delay (Ebang, Fallah, \& Pangayow, 2019). Determinan Ukuran KAP dengan kriteria Big Four pada temuan riset ini bertolak belakang dengan hasil penelitian terdahulu yang membuktikan atas pengaruh reputasi auditor, jenis dan ukuran KAP serta kualitas audit atas panjang atau pendeknya audit delay (Ezat, 2015; Prameswari \& Yustrianthe, 2015; Palilingan, 2017; Laia, Tranb, Hoang, \& Nguyen, 2020; Rusdiyanto, Agustia, Soetedjo, Narsa, \& Fitrisia, 2020; Husain \& Rini, 2020) sementara sejalan dengan hasil penelitian terdahulu yang tidak memberikan bukti faktor ukuran KAP dalam mempengaruhi audit delay (Ebang, Fallah, \& Pangayow, 2019).

\section{KETERBATASAN PENELITIAN}

Penelitian ini hanya membatasi subjek penelitian pada perusahaan-perusahaan yang melakukan 
initial public offerings (IPO) di tahun 2019 dengan pertimbangan bahwa momentum pelaporan laporan tahunan yang diaudit pada tahun 2020 masuk dalam pandemi COVID-19 yang hanya dibatasi oleh determinan faktor profitabilitas, opini audit dan ukuran KAP. Oleh karena itu, perlu dilakukan penelitian lebih lanjut di tahun berikutnya untuk mengonstruksikan kembali model penelitian dan penambahan determinan lainnya sehingga hasil penelitian mendatang dapat menghasilkan temuan penelitian ini.

\section{PENUTUP}

\section{Kesimpulan}

Hasil penelitian menghasilkan kesimpulan yaitu Audit Delay tidak dipengaruhi oleh determinan Profitabilitas, Opini Audit dan Ukuran KAP. Temuan penelitian ini memberikan implikasi pada compliance theory bahwa ketentuan Otoritas Jasa Keuangan (OJK) yang menyatakan batas waktu pelaporan tahunan perusahaan-perusahaan yang listing di BEI selambat-lambatnya 4 (empat) bulan setelah tahun buku terakhir dan adanya penundaan 2 (dua) bulan pada tahun 2020 akibat pandemi COVID-19 tetap dipatuhi oleh perusahaan-perusahaan yang melakukan IPO di tahun 2019 yang menjadi subjek pada penelitian ini.

\section{DAFTAR PUSTAKA}

Abid, A., Shaique, M., \& Anwar ul Haq, M. (2018). Do Big Four Auditors Always Provide Higher Audit Quality? Evidence from Pakistan. International Journal of Financial Studies, 6(2), 1-22.

Agoes, S. (2012). Auditing Petunjuk Praktis Pemeriksaan Akuntan oleh Akuntan Publik (Jilid-1) (4 ed.). Jakarta: Salemba Empat.

Ahmed, A. A., \& Hossain, S. (2010). Audit Report Lag: A Study of the Bangladeshi Listed Companies. ASA University Review, 4(2), 49-56.

Arens, A. A., Elder, R. J., \& Beasley, M. S. (2014). Auditing and Assurance Service, an Integrated Approach (Global ed.). England: Pearson Education Limited.

Ashton, R., Willingham, J., \& Elliott, R. (1987). An empirical analysis of audit delay. Journal of Accounting Research, 25(2), 275-292.

BAPEPAM. (2011). Peraturan Nomor X.K.2. Penyampaian Laporan Keuangan Berkala Emiten Atau Perusahaan Publik. Jakarta: Badan Pengawas Pasar Modal.

Cohen, S., \& Leventis, S. (2013). Effects of municipal, auditing and political factors on audit delay. Accounting Forum, 37(1), 40-53.

DeAngelo, L. (1981). Auditor Size and Audit Quality. Journal of Accounting and Economics, 3(3), 183-199.

Ebang, Y. B., Fallah, S., \& Pangayow, B. J. (2019). Pengaruh Ukuran Perusahaan, Profitabilitas, Solvabilitas, Opini Audit dan Ukuran Kantor Akuntan Publik terhadap Audit Delay pada Perusahaan Manufaktur di Bursa Efek Indonesia. Jurnal Akuntansi \& Keuangan Daerah, 14(2), $140-154$

Ezat, A. N. (2015). The impact of audit-related factors on audit report lag for the Egyptian listed nonfinancial companies. Journal of the Faculty of Commerce for Scientific Research, 52(2).

Gitman, L., \& Zutter, C. (2015). Principles of Managerial Finance (14 ed.). (D. Battista, Ed.) Boston: Prentice Hall.

Husain, T. (2019). An Analysis of Modeling Audit Quality Measurement Based on Decision Support Systems (DSS). European Journal of Scientific Exploration, 2(6), 1-9.

Husain, T. (2017). Analisis Determinan Faktor-Faktor Yang Mempengaruhi Niat Penggunaan Software Audit. Jurnal Ilmiah Matrik, 19(2), 131-150.

Husain, T. \& Rini, I.G.A.I.S. (2020). The Audit Quality and Delay: Evidence from Indonesia. Business Perspective Review, 2(3), 22-32.

Husain, T. \& Syniuta, A. (2020). Audit Fee and "The Big-Four": A Comparative Study at Initial Public Offerings (IPO) Companies in Indonesia Stock Exchange (IDX). Multidisciplinary European Academic Journal, 2(4), 1-7.

Husain, T., Pasupati, B., \& Quintania, M. (2020). Prediction of Audit Quality Based on Financial Ratio's: Empirical Testing. International Journal of Advanced Scientific Technologies in Engineering and Management Sciences, 6(9), 1-5.

Lai, K.-W. (2019). Audit Report Lag, Audit Fees, and Audit Quality Following an Audit Firm Merger: 
Evidence from Hong Kong. Journal of International Accounting, Auditing and Taxation, 36(C), 11 .

Laia, T. T., Tranb, M. D., Hoang, V. T., \& Nguyen, T. H. (2020). Determinants influencing audit delay: The case of Vietnam. Accounting, 6(5), 851-858.

Ocak, M., \& Özden, E. A. (2018). Signing Auditor-Specific Characteristics And Audit Report Lag: A Research From Turkey. The Journal of Applied Business Research, 34(2), 277-294.

OJK. (2020). OJK Longgarkan Batas Waktu Laporan Keuangan dan RUPS. Siaran Pers, Otoritas Jasa Keuangan, Jakarta.

OJK. (2016). Salinan Peraturan Otoritas Jasa Keuangan Nomor 29/ POJK.04/2016 Laporan Tahunan Emiten atau Perusahaan Publik. Jakarta: Otoritas Jasa Keuangan.

Palilingan, F. (2017). Analisis Faktor-Faktor yang Berpengaruh terhadap Audit Delay. Jurnal Akuntansi, 6(1), 32-46.

Prameswari, A. S., \& Yustrianthe, R. H. (2015). Analisis Faktor-Faktor Yang Mempengaruhi Audit Delay (Studi Empiris pada Perusahaan Manufaktur yang Terdaftar di Bursa Efek Indonesia). Jurnal Akuntansi, XIX(01), 50-67.

Rusdiyanto, Agustia, D., Soetedjo, S., Narsa, I. M., \& Fitrisia, D. S. (2020). Determinants of audit delay in indonesian companies: empirical evidence. Revista ESPACIOS, 41(03), 24-29.

Santosa, A. D. (2019). Analisis Multivariat (Cetakan Ketiga) (3 ed.). Yogyakarta: Penerbit Kepel Press.

SEC. (2002). Acceleration of Periodic Report Filing Dates and Disclosure Concerning Website Access to Reports, Release No. 33-8128. Washington, D.C.: U.S. Securities and Exchange Commission.

SPAP. (2010). Standar Profesional Akuntan Publik. Jakarta: Institut Akuntan Publik Indonesia.

Sugiyono. (2017). Metode Penelitian Evaluasi: Pendekatan Kuantitatif, Kualitatif, dan Kombinasi. Bandung: CV. Alfabeta.

Supranto, J., \& Limakrisna, N. (2019). Petunjuk Praktis Penelitian Ilmiah untuk Menyusun Skripsi, Tesis dan Disertasi (5 ed.). Bogor: Penerbit Mitra Wacana Media.

Svanström, T. (2013). Non-audit services and audit quality: evidence from private firms. European Accounting Review, 22(2), 337-366.

Tayler, T. (1990). Why People Obey the Law. New Haven and London: Yale University Press.

Wijayanti, Y. P., Machmuddah, Z., \& Utomo, S. D. (2019). Audit Delay: Case Studies at Conventional Banking in Indonesia. Journal of Innovation in Business and Economics, 03(01), 33-40. 